\title{
Training of Future Education Managers For Professional Activities
}

\section{Formación de futuros directores de educación para actividades profesionales}

\author{
Iana Viktorovna Poliakova
}

Donbass Law Academy, Donetsk, Ukraine

https://orcid.org/0000-0003-4108-6691

\section{Dmitry Vladimirovich Lukashenko}

Research Institute of The Federal Penitentiary Service of The Russian Federation, Moscow, Russia https://orcid.org/0000-0002-0045-6062

\section{Irina Stanislavovna Andryushchenko}

Peoples' Friendship University of Russia (Rudn University), Moscow, Russia https://orcid.org/0000-0003-4222-4865

\section{Polina Mihaylovna Alekseeva}

Saint-Petersburg State University Of Aerospace Instrumentation, Saint-Petersburg, Russia https://orcid.org/0000-0001-7960-2351

\section{Marina Georgiyevna Sergeeva}

Research Institute Of The Federal Penitentiary Service of Russia, Moscow, Russia https://orcid.org/0000-0001-8365-6088

*Correspondencia

Email: y_polyakova@rambler.ru

\section{Citar como:}

Poliakova, I.V., Lukashenko, D.V., Andryushchenko, I.S., Alekseeva, P.M., \& Sergeeva, M.G. Poliakova, I.V (2021) Training of Future Education Managers For Professional Activities. Propósitos y Representaciones, 9(SPE2), e1106. http://dx.doi.org/10.20511/pyr2021.v9nSPE2.1106 


\section{Summary}

Large-scale changes in the social and economic spheres of Russian society revealed the demands for managers with non-standard thinking and a high cultural level. Specific and ambiguous processes in politic, economic and social spheres in different parts of the world have general trends reflecting the evolution of global civilization. In this context, educational systems received new functions aimed at moral growth and improvement of competencies. The highest demand in the field of education is for experienced teachers and administrators who are able to improve the system of education and upbringing, develop scenarios for managing the teaching and learning process, offer the personality-oriented trajectories for students, make an independent choice and fulfill corrective and diagnostic functions. The transformed socioeconomic context led to positive changes in the field of professional education. One of the basic features of the modern educational systems is the training of highly qualified education managers. Such individual characteristics as the ability to continuous self-improvement, creativity, communication skills, entrepreneurial skills, the ability to analyze and foresee, etc. play an increasing role in the professional training. The most important place in the training of education managers is occupied by pedagogical technologies aimed at mastering the necessary competencies in economics, management, psychology and related disciplines. In the context of the innovative transformations of Russian education, the pressing need to integrate new management schemes into the practice of educational institutions and the problem of pedagogical training in the field of management becomes very urgent. Qualified management creates conditions for improving the educational environment, increasing the quality of educational services. The educational system should prepare young citizens capable of making a feasible contribution to the formation of the law-based state. Currently, it is necessary to optimize the activities of education managers responsible for the implementation of the state programs to improve and innovate the economy, science and education. The management culture of education managers is beginning to play a decisive role in the creation of a democratic society in the Russian Federation based on respect for individual rights and freedoms. The creation of the most favorable conditions for the integration of students into the educational and cultural environment is aimed at creating a high level of management culture of future education managers.

Keywords: Professional training, education manager, management culture, professional activity.

\section{Resumen}

Los cambios a gran escala en las esferas social y económica de la sociedad rusa revelaron las demandas de gerentes con un pensamiento no estándar y un alto nivel cultural. Los procesos específicos y ambiguos en las esferas política, económica y social en diferentes partes del mundo tienen tendencias generales que reflejan la evolución de la civilización global. En este contexto, los sistemas educativos recibieron nuevas funciones orientadas al crecimiento moral y la mejora de competencias. La mayor demanda en el campo de la educación es de maestros y administradores experimentados que sean capaces de mejorar el sistema de educación y crianza, desarrollar escenarios para la gestión del proceso de enseñanza y aprendizaje, ofrecer trayectorias orientadas a la personalidad para los estudiantes, hacer una elección independiente y cumplir funciones correctivas y de diagnóstico. El contexto socioeconómico transformado condujo a cambios positivos en el campo de la educación profesional. Una de las características básicas de los sistemas educativos modernos es la formación de gestores educativos altamente cualificados. Características individuales como la capacidad de superación continua, la creatividad, la capacidad de comunicación, la capacidad empresarial, la capacidad de análisis y previsión, etc., juegan un papel cada vez más importante en la formación profesional. El lugar más importante en la formación de gestores educativos lo ocupan las tecnologías pedagógicas destinadas a dominar las competencias necesarias en economía, gestión, psicología y disciplinas afines. En el contexto de las transformaciones innovadoras de la educación rusa, la urgente necesidad de integrar nuevos esquemas de gestión en la práctica de las instituciones educativas 
y el problema de la formación pedagógica en el campo de la gestión se vuelve muy urgente. La gestión calificada crea las condiciones para mejorar el entorno educativo, aumentando la calidad de los servicios educativos. El sistema educativo debe preparar ciudadanos jóvenes capaces de hacer una contribución viable a la formación de un Estado basado en la ley. Actualmente, es necesario optimizar las actividades de los gestores educativos responsables de la implementación de los programas estatales para mejorar e innovar la economía, la ciencia y la educación. La cultura de gestión de los directores de educación está empezando a desempeñar un papel decisivo en la creación de una sociedad democrática en la Federación de Rusia basada en el respeto de los derechos y libertades individuales. La creación de las condiciones más favorables para la integración de los estudiantes en el entorno educativo y cultural tiene como objetivo crear un alto nivel de cultura de gestión de los futuros gestores educativos.

Palabras clave: formación profesional, gestor educativo, cultura de gestión, actividad profesional.

\section{Introduction}

The educational environment, more than any other environment of human activity, is characterized by a high degree of complexity. The educational environment possesses a heightened emotional perception of the processes taking place in it, and includes various conflicts of interests of its participants. Conflict in itself is not considered a negative characteristic. It is a necessary element of the existence of any team. Competent administration of an educational institution should transfer conflicts into the healthy competition, aimed at solving professional tasks (Vasilyeva, Sokolova, Mikheeva, 2017).

The profession of a manager is distinguished by the complexity, multitasking and a high level of personal responsibility inherent in managerial activity in general, as well as the lack of clear criteria for assessing qualifications and the dependence of professional activity on the qualities and properties of the individual (Filimanuk et al., 2018).

We examined in more detail the essential features of management culture in the field of education. It should be noted that without a highly developed management culture, it is impossible not only to effectively perform administrative functions, but also to effectively operate an educational institution as a whole.

Leadership qualities, professional skills and management competencies, psychological intuition, personal values are necessary for the head of any organization, but especially for the head of an educational institution. The educational environment is characterized by a high degree of complexity, numerous collisions of interests of the persons acting in it. A leader who does not possess the management culture can hardly create a favorable climate in the team, reduce the degree of conflicts and transfer conflicts into a constructive interaction. Such a leader will not be a recognized authority for the subordinate employees, and his/her managerial decisions will meet significant resistance in the team (Sokolova, 2003).

The complexity of the educational environment lies in the fact that not only managers and ordinary employees are involved in its life. The most important participants are students. Managerial failures of the head of an educational institution or his/her deputies can have a negative impact on all areas of professional interaction, both horizontally (between administrators) and vertically (between administration and teaching staff, etc.). The managerial incompetence of the administration of an educational institution will negatively affect the quality of the educational and upbringing process, lead to a loss of trust on the part of students and parents, to an increase in the conflict potential at all levels, and to the involvement of students and their parents in conflicts.

In addition to professional education and practical skills, the ability of a manager to improve the efficiency of professional activity, to constant development of managerial skills is 
of particular importance. Another criterion for assessing the management culture is that an education manager should be able to regulate relations in a team, create a favorable psychological climate, and form organizational culture.

The head of an educational institution should be focused on solving pedagogical, social and psychological problems that arise in the team. Psychological research concerning the teaching staff proves that managers are predominantly focused on organizational and technical problems. If the manager is not focused on solving individual problems of the staff members, then it affects the efficiency of the team as a whole. In modern conditions, the external and internal factors are becoming more complex, the requirements for the educational institution and for the administration are increasing.

\section{Literature review}

According to the Russian researcher T.O. Tretyakova, the management culture is a complex system that includes the sum of professional competencies and orientations. This approach to the issue allows:

- firstly, to study the management culture as a whole, as a system;

- secondly, to consider the content of management culture as an element in the professional growth of university graduates; 2016).

- thirdly, to plan the use of pedagogical methods in this process (Tretyakova, Limberov,

Various authors pay great attention to the development of the management culture of graduates (both bachelor's and master's degrees). So, for example, T.P. Makarova actualizes the role of managerial culture of university graduates:

- management culture can play the role of a socio-cultural regulator of public life in an information society;

- management culture is a system-forming factor in society, since it is present in the activities of every element of society;

- rational use of intellectual resources depends on the management culture (Makarova, 2016).

Russian educator A.A. Maury considers the management culture as a combination of professional knowledge, abilities and skills, personal qualities allowing to effectively carry out managerial activities on the basis of constant self-improvement (Mauri, 2010).

The foundations of the management culture of future education managers are laid during the training period. Therefore, we believe, firstly, the problem of forming the management culture of university graduates at the present stage is related to the extent to which the administration of higher education institutions can lay the necessary foundations for each graduate. And it is necessary to start, of course, with the head of higher education institution, his/her leadership qualities, personal and professional characteristics, due to which he/she can be an example for graduates, a role model to be followed. Secondly, it should be noted that the level of management culture of university graduates is far from the same if we consider the economic or technical areas of training (Volkova, Panchenko, 2018).

Russian and foreign management theorists (Gorev et al., 2018; Blinova, Dugina, Zabolotskikh, 2018; Sokolova, 2007; Vasbieva et al., 2018; Akhmedova et al., 2018) are trying 
to formulate some general criteria of a successful manager. These criteria relate to both the professional competencies and personal qualities. Some of these criteria are of a general nature, but in the field of education there is the specificity of the management process, which expands and complicates the concept of management culture in this area of human activity.

The general criteria of a manager with a highly developed management culture include the level of professionalism, organizational and communication skills, and a willingness to innovate. A manager should be practically oriented in social psychology, be familiar with modern political and cultural processes, have a developed sense of taste, style, a high level of moral and intellectual culture (Bírová et al., 2018; Dolzhich, Dmitrichenkova, 2018; Sokolova, 2018).

\section{Research methodology}

In the scientific literature (Sharonova, Trubnikova, Sokolova, 2018; 5, Pryazhnikov et al., 2018) there are many definitions of management style. To summarize them, the management style is a system that is quite stable and characterized by certain ways and methods of the manager's activity. The manager uses these methods and ways to influence employees and decision making.

\begin{tabular}{|l|l|l|}
\hline $\begin{array}{l}\text { Organizational relations } \\
\text { type }\end{array}$ & $\begin{array}{l}\text { Ways of management and } \\
\text { administration }\end{array}$ & $\begin{array}{l}\text { Management positions of } \\
\text { the head }\end{array}$ \\
\hline $\begin{array}{l}\text { Social and emotional relations } \\
\text { (relations of interpersonal and } \\
\text { group solidarity) }\end{array}$ & $\begin{array}{l}\text { Informal leadership (socio- } \\
\text { psychological type of } \\
\text { dominance in } \\
\text { organization) }\end{array}$ & $\begin{array}{l}\text { The informal leader of the } \\
\text { organization a professional } \\
\text { with special personal qualities } \\
\text { an capable to influence } \\
\text { others }\end{array}$ \\
\hline $\begin{array}{l}\text { Business relations (relations } \\
\text { of maximum interest and } \\
\text { profitability) }\end{array}$ & $\begin{array}{l}\text { Management as business in } \\
\text { the long term }\end{array}$ & $\begin{array}{l}\text { Administrator as a } \\
\text { professional capable of } \\
\text { effectively managing an } \\
\text { organization in a changing } \\
\text { market environment and } \\
\text { taking into account strategic } \\
\text { initiatives }\end{array}$ \\
\hline $\begin{array}{l}\text { Instrumental relations } \\
\text { (relations of technical } \\
\text { execution of projects and } \\
\text { tasks) }\end{array}$ & $\begin{array}{l}\text { Administration as a traditional } \\
\text { way of day-to-day } \\
\text { management of the } \\
\text { organization }\end{array}$ & $\begin{array}{l}\text { Administrator as the } \\
\text { organizer of the execution of } \\
\text { current task and projects } \\
\text { initiated by higher officials }\end{array}$ \\
\hline $\begin{array}{l}\text { Power relations (relations } \\
\text { associated with the exercise of } \\
\text { formal, legitimate power) }\end{array}$ & $\begin{array}{l}\text { System of official legitimate } \\
\text { power in an organization, } \\
\text { carried out on an elective } \\
\text { basis or by appointment }\end{array}$ & $\begin{array}{l}\text { Formal leader of the } \\
\text { organization as a managerial } \\
\text { officer, elected or appointed } \\
\text { to the head position }\end{array}$ \\
\hline
\end{tabular}

(Figure 1): The main types of organizational relations and the corresponding management positions of the head

Management style, like any phenomenon, is created under the influence of conditions and factors determined by circumstances. These conditions and factors include one-dimensional and multi-dimensional relations. One-dimensional relations take into account one factor, and multidimensional relations take into account several factors and circumstances in the process of building relations.

In the theory of leadership by Kurt Lewin, one-dimensional management styles include authoritarian (directive), democratic (participative), and liberal (delegative). The modern leader should be flexible enough and understand the needs of employees and own needs. In order to apply effective management methods the leader should clearly understand the tasks facing the 
structural subdivision or the whole company. The leader must, if necessary, quickly fulfill the task of the superior manager, optimally combine a good administrator and an effective leader. Such a leader must be recognized by all subordinates. But the main characteristic of the leader status is the legitimacy, which gives grounds to exercise powers on a legal basis.

"Pure management styles" are practically not found, and the most popular is the authoritarian-democratic style, as is known from the theory and practice of management. It allows the leader to implement the principle of collegiality, in which the performance of tasks is entrusted to subordinates and the initiative of employees in decision-making is encouraged, and, at the same time, to implement the principle of one-man management, which assumes that each employee is subordinate to only one manager.

F. Taylor, M. Porter and other researchers paid special attention to the structural characteristics of the manager. Igor H. Ansoff, M. Woodcock, V.I. Kurbatov, B.I. Tsukanov believed that the human factor and psychological characteristics of the manager play a significant role in making management effective. The factors that have a reducing effect on the work of the manager are presented in Figure 2.

\begin{tabular}{|c|c|}
\hline \multicolumn{2}{|c|}{ Factors } \\
\hline $\begin{array}{l}\text { The manager does not plan work } \\
\text { (neither his/her own, nor his/her unit ) }\end{array}$ & $\begin{array}{l}\text { The manager does not know how to } \\
\text { optimally use subordinates in the } \\
\text { interests of work }\end{array}$ \\
\hline $\begin{array}{l}\text { The manager does pleasant and } \\
\text { familiar work at first }\end{array}$ & $\begin{array}{l}\text { The manager directs the work of } \\
\text { personnel directly, rather than to lead }\end{array}$ \\
\hline & $\begin{array}{l}\text { by setting goals and objectives, } \\
\text { relying on self-management }\end{array}$ \\
\hline
\end{tabular}

The manager does not trust his/her subordinates and performs their job himself/herself

The manager does not know his/her subordinates and is not interested in their work, their personal career plans for the future

The manager does not want to or can not talk openly with employees

The manager does not believe in the abilities of subordinates

The manager makes a lot of decisions for subordinates, believing that in this way he/she keeps all the threads of management in the hands, but in fact slows down the development of subordinates in matters of decisionmaking, overloads with work

\section{(Figure 2): Factors reducing the effectiveness of a manager}

The development of a graduate's personality in the dimension of management culture is based on methodological approaches described in Table 1 (Akhmedova et al., 2019).

(Table 1): Methodological approaches to modeling the management culture development of a future education manager in the process of professional training in a higher educational institution 


\begin{tabular}{|l|l|}
\hline $\begin{array}{l}\text { Methodological } \\
\text { approach }\end{array}$ & Functionality of the approach \\
\hline System approach & $\begin{array}{l}\text { It is focused on modeling the development of management culture as a } \\
\text { system, based on pedagogical paradigms and philosophy of the } \\
\text { individual }\end{array}$ \\
\hline $\begin{array}{l}\text { Competency-based } \\
\text { approach }\end{array}$ & $\begin{array}{l}\text { It reveals the content of the formed management competency, described } \\
\text { the structure and the expected outcomes }\end{array}$ \\
\hline Activity approach & $\begin{array}{l}\text { It determines the position of the student as the subject of cognition, } \\
\text { communication, creativity }\end{array}$ \\
\hline $\begin{array}{l}\text { Integrative } \\
\text { Differentiated } \\
\text { Approach }\end{array}$ & $\begin{array}{l}\text { It implements the ideas of interaction in the field of integration and } \\
\text { differentiation of pedagogical and psychological aspects in the model of } \\
\text { the management culture of future education managers }\end{array}$ \\
\hline $\begin{array}{l}\text { Learner-centered } \\
\text { approach }\end{array}$ & It is aimed at the development of the individual in the learning process \\
\hline
\end{tabular}

For our study, it is important to consider the interconnection of the above approaches, their complementarity and integration, since it ensures the greatest efficiency in solving the assigned tasks.

\section{Result Analysis}

The process of the management culture development included several stages of experimental work.

At the indicative stage, the initial level of the management culture of students was determined:

- the motivation professional interests and inclinations of students;

- the level of knowledge, skills and abilities required in the field of management activities;

- the readiness of students to adopt the organizational and management culture necessary for future professional activity.

At the formative stage, the development of organizational and management culture among students was performed. Attention was focused on the system of creative assignments with the elements of scientific research (participation in special courses and research seminars, preparation of analytical reports, term papers, etc.), since they are an effective way of mastering the methodology of management activities. Creative assignments allow structuring the educational material of disciplines, united by one scientific idea and method of cognition, and then extrapolating the result to other similar economic systems and situations.

The basic element is reliance on previous knowledge, continuity in the content of the presented material, interdisciplinary connections. The development of priority scientific ideas and directions underlying management activities affects the quality of the social and production environment, indicators of economic growth, market stability of the organization, successful functioning, prospects for strategic development.

At this stage the students developed research skills, learned to analyze economic information, to determine ways and means of implementing managerial decisions in a specific situation, to predict the results and possible consequences of their decisions. Creative tasks 
allow students to intensify educational activities and contribute to the development of professional thinking, ensure the gradual mastery of the basics of management culture.

At the same time, at the formative stage, the effectiveness of individual elements of professional training was assessed. The level of management culture was revealed in the readiness of graduates to implement managerial functions, develop, create, maximize effective use and control of socio-economic systems, by making and implementing informed managerial decisions.

The management culture of graduates requires special attention to the organization of various types of professional practical training. One of the tasks of educational and in-service practice is the development of management culture.

At the concluding stage of the experimental work, the final diagnostics of the qualitative characteristics of the management culture is carried out. As at the indicative stage in the process of diagnostics, methods of multidimensional research of personality orientation and assessment of management culture were used.

The criteria for the effectiveness of the management culture development in the process of professional training at the higher educational institution are as follows:

- the degree of completeness and consistency of theoretical knowledge in the field of management and the need of professional reflection based on the accepted values of management culture;

- the degree of mastering professional skills (practical management skills);

- the degree of development of the general and professional abilities of the future manager;

- the degree of development of the professionally important qualities of the manager and the structural components of the management culture.

\begin{tabular}{|c|c|c|c|c|}
\hline \multicolumn{2}{|c|}{$\begin{array}{lr}\text { Requirements } & \text { for } \\
\text { education } & \text { and } \\
\text { management culture }\end{array}$} & \multicolumn{2}{|c|}{$\begin{array}{l}\text { Manager } \\
\text { functions }\end{array}$} & Basic professional competencies \\
\hline \multicolumn{4}{|c|}{ Goal: development of management culture } & \multirow[b]{2}{*}{$\begin{array}{l}\text { Indicators of the development: } \\
\text { - assimilation of means and methods of } \\
\text { work, development of structural } \\
\text { components of management culture; } \\
\text { - organization of professional activity } \\
\text { based on the accepted values of } \\
\text { management culture; } \\
\text { - the effectiveness of solving } \\
\text { professional problems }\end{array}$} \\
\hline \multicolumn{4}{|c|}{ Organizational and educational conditions } & \\
\hline \multicolumn{4}{|c|}{ Educational process } & \multirow{2}{*}{$\begin{array}{l}\text { Outcomes: } \\
\text { Development of management culture: } \\
\text { low; medium; high }\end{array}$} \\
\hline $\begin{array}{l}\text { Teacher's } \\
\text { activity }\end{array}$ & $\begin{array}{l}\text { Content, } \\
\text { methods, forms, } \\
\text { educational } \\
\text { technologies }\end{array}$ & $\begin{array}{l}\text { Students' } \\
\text { activity }\end{array}$ & $\begin{array}{l}\text { Types } \\
\text { of } \\
\text { training }\end{array}$ & \\
\hline
\end{tabular}

(Figure 3): Model of the management culture development of future education managers 
The proposed model made it possible to adequately design a program for the development of the management culture of future education managers. The model was also used as a diagnostic and forecasting tool.

\section{Conclusion}

The importance of education as one of the foundations of the complex and dynamic development of society is postulated in the National Doctrine of Education of the Russian Federation, which sets the key trajectories for the modernization of the educational system. The management culture of future education managers is an important indicator of the performance of a specialist in the field of management and education. Management culture is an integral part of pedagogical culture.

The essence of the management culture of an education manager in the feasibility and comprehensive representation of the culture-centric model, the implementation of creative management at the stages associated with self-government and the organization of the creative educational process.

We consider the most promising methodological approaches to the development of the management competency of future education managers are systemic, activity-based, competency-based, individual, anthropological and cultural approaches. The last two approaches implement cultural resources focused on the human personality.

The level of a professional's individual culture depends on the assimilation of the cultural experience accumulated by previous generations and the ability to renew the existing cultural tradition. Material values created by people constitute the external aspect of culture, its shell, while its essence is the unleashing of the inner potential of a person, capable and called upon to continuous self-creation and self-improvement. The main criterion of the intellectual and moral level is the attitude towards the people around, inanimate reality (nature, law, arts) and oneself.

\section{Referencias}

Akhmedova, E.M., Pozdnikova, I.R., Micherina, I.V., Kolosova, N.V., Pashina, S.A., Uvarova, N.N. (2019). Art pedagogical space as an innovative environment for creative development of a child. Man-Power-Law-Governance: Interdisciplinary Approaches: materials of the international scientific conference. Amsterdam: Atlantis Press.

Akhmedova, E.M., Taranova, T.N., Khalyapina, L.V., Khokhlova, D.A., Nedopovz, I.I., Kirillova, M.I. (2018). Transdisciplinarity approach to the formation of graduate students competence value-semantic orientation in the educational area of society. The Turkish Online Journal of Design, Art and Communication. TOJDAC, 8(4). http://dx.doi.org/10.7456/1080SSE/31

Bírová, J., Kružlík, P., Kalimullin, A., Sokolova, N., Haroun, Z., Králik, R., Vasbieva, D. (2018). Mathematical and Statistical Bibliometric Indicators for Scholars in the Field of Romance Languages and Linguistics. EURASIA: Journal of Mathematics, Science and Technology Education, 14(12).

Blinova, S., Dugina, T., Zabolotskikh, A. (2018). Teaching mixed nationality groups (on the example of students from the Northern Caucasus region). INTED2018: Proceedings of the 12th International Technology, Education and Development Conference (pp. 7977 7982). Valencia, Spain.

Dolzhich, E., Dmitrichenkova, S. (2018). Computer science terminology (a case study of the Spanish language). INTED2018: Proceedings of the 12th International Technology, Education and Development Conference (pp. 2556-2559). Valencia, Spain.

Filimanuk, L.A., Khalyapina, L.V., Chebanov, K.A., Uvarova, N.N., Soloveva, E.V., Akhmedova, E.M. (2018). Formation of value sensitive orientation in the educational 
space of society competence of magistracy students of psychological-pedagogical course. Journal of Fundamental and Applied Sciences. Algeria, 10(5), 1007-1019. http://dx.doi.org/10.4314/jfas.v10i5s.8

Gorev, P., Telegina, N., Karavanova, L., Feshina, S. (2018). Puzzles as a didactic tool for development of mathematical abilities of junior schoolchildren in basic and additional mathematical education. EURASIA: Journal of Mathematics, Science and Technology Education, 14(10), 178-185.

Makarova, T.P. (2016). Model of the formation of the managerial culture of students - future civil servants in the educational process of the university. Bulletin of the Russian International Academy of Tourism, 2, 113-118.

Mauri, A.A. (2010). The essence and content of managerial culture of managers in modern socio-cultural conditions. Kirov.

Pryazhnikov, N.S., Rumyantseva, L.S., Sokolova, N.L., Bakhtigulova, L.B. (2018). Career guidance: harmonization of points of view. Scientific dialogue, 3, 289-303.

Sharonova, S., Trubnikova, N., Sokolova, N. (2018). Interpreting religious symbols as basic component of social value formation. European Journal of Science and Theology, 14(3), 117-129.

Sokolova, N.L. (2003). On the components of the meaning of the units of speech etiquette. Philological sciences, 5, 95.

Sokolova, N.L. (2007). Thematic group "Acquaintance" in the English-speaking culture of communication. Bulletin of the Moscow State Linguistic University, 532, 218-227.

Sokolova, N.L. (2018). Professional evolution of a school teacher based on advanced pedagogical experience. Scientific dialogue, 9, 376-381.

Tretyakova, T.O., Limberov, N.V. (2016). Management consulting. Sociology of management: textbook. Chita: ZabGU.

Vasbieva, D.G., Sokolova, N.L., Masalimova, A.R., Shinkaruk, V.M., Kiva-Khamzina, Y.L. (2018). Exploring the EFL teacher's role in a smart learning environment - a review study. XLinguae, 11(2), 265-274.

Vasilyeva, I.I., Sokolova, N.L., Mikheeva, N.F. (2017). Some trends in the use of ICT in Russian scientific research in the field of teaching foreign languages and translation in universities (2012-2017). Problems of Applied Linguistics, 27, 7-18.

Volkova, Y., Panchenko, N. (2018) Discourse variation of the concepts of destructive emotions. Vestnik Rossiiskogo Universiteta Druzhby Narodov. Russian journal of linguistics, 22(1), 175-194. 